\title{
CTLA-4 gene+49 A/G polymorphism in prostate cancer patients in Turkish population
}

\begin{abstract}
Background: Cytotoxic T-lymphocyte antigen 4 (CTLA-4), the T cell surface antigen is expressed during activation. Prostate cancer ( $\mathrm{PCa}$ ) is one of the most common cancers in Western population and its rate is increasing in the Eastern World. The aim of this study was to evaluate cytotoxic T lymphocyte associated antigen-4 (CTLA-4) gene $+49 \mathrm{~A} / \mathrm{G}$ polymorphisms in prostate cancer patients
\end{abstract}

Material and methods: This study included 119 (mean age: $68.94 \pm 8.38$ years) healthy controls and 62 (mean age: $72.83 \pm 7.60$ years) patients with prostate cancer. The CTLA-4 gene+49A/G (rs231775) gene regions were amplified using polymerase chain reaction (PCR), detected by restriction fragment length polymorphism (RFLP).

Results: At the end of our study, it was found that the prevalence of genotypes of AA (wild-type), AG (heterozygous mutant) and GG (homozygous mutant) profiles for the CTLA-4 gene $+49 \mathrm{~A} / \mathrm{G}$ polymorphism were $50 \%, 45 \%$ and $5 \%$ respectively in prostate cancer patients, and $56 \%, 36 \%$ and $8 \%$ respectively in healthy control groups.

Conclusion: No association was found in terms of the CTLA-4 gene $+49 \mathrm{~A} / \mathrm{G}$ polymorphism among prostate cancer patients and the control groups in Turkish population

Keywords: polymorphism, prostate cancer, CTLA-4 gene, PCR, RFLP
Volume 2 Issue 5 - 2017

\author{
Songül Budak Diler \\ Department of Biotechnology, University of Niğde Ömer \\ Halisdemir, Turkey
}

\begin{abstract}
Correspondence: Songül Budak Diler, Department of Biotechnology, Faculty of Science and Letters, University of Niğde Ömer Halisdemir, Niğde, Turkey, GSM 0532 6504828, Tel 0388 2254060,Email budakdiler@gmail.com, sdiler@ohu.edu.tr
\end{abstract} Received: November 20, 2017 | Published: November 30,
2017

\section{Introduction}

Cancer is a multifactorial disease caused by complex interactions between the genetic and environmental factors. ${ }^{1}$ Prostate cancer $(\mathrm{PCa})$ is the most common malignancy in man worldwide and its rate is increasing in both developed and developing countries. ${ }^{2}$ The etiology of cancer is complicated and not exactly known. For this reason, recent studies have focused on the role of the immune system. There are two important steps in tumorigenesis that include the abduction of immune surveillance by tumor cells and the generation of immunosuppressive cytokines. Therefore, tumor immunity is known as a hot spot in cancer research. The most significant antitumor reply is cell-mediated and includes T lymphocytes and the natural killer (NK) cells. Therefore, genetic polymorphisms in the human genome regulating the activation and proliferation of $\mathrm{T}$ lymphocytes and NK cells may influence the risk of cancer. ${ }^{1}$ Cytotoxic T-lymphocyte antigen 4 (CTLA-4) gene is located in chromosome 2 (2q33). ${ }^{3}$ Single nucleotide polymorphisms (SNPs) in the CTLA-4 gene have been linked to the sensitivity to autoimmune disease, but, the studies conducted in recent years suggested that the $49 \mathrm{~A} / \mathrm{G}$ polymorphisms in CTLA-4 are risk factors for cancer. Many $(>100)$ SNPs have been identified in the CTLA-4 gene that contains three exons and two introns. Some of these are, the $-318 \mathrm{C} / \mathrm{T}$ SNP (rs5742909) located in the promoter region, the 49A/G SNP (rs231775) located in exon 1, and the 6230A/G SNP (CT60, rs3087243) located in 3'-untranslated region (3'UTR). ${ }^{1,4}$

Many studies demonstrated that these 3 (the CTLA-4 gene $+49 \mathrm{~A} / \mathrm{G}$, the CTLA-4 gene $-318 \mathrm{C} / \mathrm{T}$, and the CTLA-4 gene $6230 \mathrm{~A} / \mathrm{G}$ ) polymorphisms were involved in the etiology of various cancers, including cervical cancer, lung cancer, breast cancer, hepatocellular cancer, and osteosarcoma. ${ }^{5-8}$ In addition, in many epidemiologic studies conducted so far, the 49A/G SNP (rs231775) in the CTLA4 that causes a threonineto-alanine substitution in codon 17 has been found to be associated with genetic susceptibility to cancer in several populations. ${ }^{1,49}$ The different polymorphisms in CTLA4 gene have been analyzed on patients with inflammatory bowel disease, ${ }^{10-12}$ diabetes. ${ }^{13-15}$ and various cancer. ${ }^{5,8,16}$ Therefore, we aimed at investigating the significance of CTLA- 4 gene +49 A/G single nucleotide polymorphisms in patients diagnosed with prostate cancer in this study.

\section{Material and Methods}

\section{Subjects}

The subjects were studied retrospectively and included 62 patients with PCa (mean age $72.83 \pm 7.60$ years), and 119 unrelated healthy volunteers (mean age $68.94 \pm 8.38$ years) as controls (Table 1). The patients and controls were selected among the ones from the urology clinic of Lüleburgaz and Niğde State Hospitals, Turkey. The DNA samples used in this study were obtained from the blood samples previously taken under 'The Investigation of Endothelial Nitric Oxide Synthase Gene Polymorphisms in Prostate and Bladder Cancer' titled project within the scope of ethical report (Cukuroava University, Ethics Committee for Clinical Researches/KAEK 2013-29), in which both the patients and healthy volunteers were informed and their approvals were obtained and the DNA samples were used in accordance with the GOKAEK 2016/93 (Kocaeli University, Ethical Committee for Clinical Researches) numbered ethical report. The patients previously diagnosed with prostate cancer were included in this study as the main case group. The control group was selected from among volunteers without prostate cancer and the individuals with any kind of cancer history in the same population.

\section{DNA extraction}

Peripheral blood samples were collected from the participants 
in ethylenediaminetetraacetic acid (EDTA) tubes. Genomic DNA was extracted from $200 \mu \mathrm{L}$ EDTA-anticoagulated peripheral blood leukocytes using the QIAamp DNA Blood Mini Kit(QIAGEN GmbH, Maryland, USA), in accordance with guidelines of the manufacturer. The extracted DNA samples were stored at $-20^{\circ} \mathrm{C}$ until analysis.

Table I The demographic characteristics of patients with prostate cancer (PCa), and the healthy controls

\begin{tabular}{|c|c|c|c|c|}
\hline Parameters & & $\begin{array}{l}\text { Patients } \\
(n=62)\end{array}$ & $\begin{array}{l}\text { Control groups } \\
(n=|| 9)\end{array}$ & $P$ value \\
\hline $\begin{array}{l}\text { Age } \\
\text { Sex (Male) }\end{array}$ & & $72.83 \pm 7.60$ & $68.94 \pm 8.38$ & 0.003 \\
\hline \multirow{2}{*}{$\begin{array}{l}\text { Smoking } \\
\text { status }\end{array}$} & Yes & $12(69.66 \pm 6.40)$ & $44(67.70 \pm 8.39)$ & 0.456 \\
\hline & No & $50(73.60 \pm 7.72)$ & $75(69.67 \pm 8.34)$ & 0.009 \\
\hline
\end{tabular}

\section{Genotyping}

Genotyping of polymorphic restriction sites in the CTLA-4 gene exon 1 position 49 was done by using PCR amplification followed by the restriction fragment length polymorphism (RFLP) method. ${ }^{3}$ A $162 \mathrm{bp}$ fragment of the CTLA-4 gene was amplified by PCR with the following primers: forward 5'-GCTCTACCTCTTGAAGACCT-3' and reverse 5'-AGTCTCACTCACCTTTGCAG-3'. The amplifications were conducted under the following reaction conditions: initial denaturation at $94^{\circ} \mathrm{C}$ for 3 minutes followed by 35 cycles of denaturation at $94^{\circ} \mathrm{C}$ for 45 seconds, annealing at $60^{\circ} \mathrm{C}$ for 45 seconds and extension at $72^{\circ} \mathrm{C}$ for 45 seconds and completion with $72^{\circ} \mathrm{C}$ extension for 5 minutes. All of the PCR products were electrophoresed on a $1.5 \%$ agarose gel with $1 \times$ Tris-borate-EDTA buffer at $100 \mathrm{~V}$ for 30 minutes and then observed under ultraviolet illumination. ${ }^{3}$ After the PCR, amplicons were digested by endonuclease BbvI (Fermentas, Burlington, USA) at $37^{\circ} \mathrm{C}$ during $10 \mathrm{~min}$ followed by heating at $65^{\circ} \mathrm{C}$ for 10 minutes in accordance with the instructions of the manufacturer. Endonuclease $\mathrm{BbvI}$ recognizes the polymorphic sequence and cuts after nucleotides in two fragments of $88 \mathrm{bp}$ and $74 \mathrm{bp}$. The generated fragments were separated by $2,5 \%$ agarose gel electrophoresis containing ethidium bromide, followed by exposure to ultraviolet light. All samples were genotyped and the genotyping was classified as follows: AA (162bp), AG (162bp, 88bp, and 74bp), and GG (88bp and 74bp) [3].

\section{Statistical analysis}

The SPSS 15.0. package for Windows (SPSS Inc., Chicago, IL, USA) was used for the statistical analysis. The baseline characteristics were tested using the Student $t$ test for equal variances. These data are expressed as the mean \pm SD. The comparisons of genotype and allelic frequencies among the different groups (prostate cancer patients and controls) were performed by means of chi-square test. For each polymorphism, unconditional logistic regression was used to calculate odds ratios (OR) and $95 \%$ confidence intervals $(95 \% \mathrm{CI})$ for prostate cancer. The Hardy-Weinberg equilibrium test was used to test the distributions of mutation genotype frequency. The deviations from Hardy-Weinberg equilibrium were analyzed by using Michael H. Court's (2005-2008) online calculator.

\section{Results}

This study included 119 (mean age:68.94 \pm 8.38 years) healthy controls and 62 (mean age:72.83 \pm 7.60 years) patients with PCa. The control group consisted of 119 unrelated healthy male aged between 50 and 80 years. The demographic characteristics (age, sex, and smoking status) of patients, and the control groups are shown in Table 1 .

All analyzed polymorphisms were in Hardy-Weinberg equilibrium both in $\mathrm{PCa}$ patients and healthy controls. When the genotype frequencies of the CTLA-4 gene $+49 \mathrm{~A} / \mathrm{G}$ polymorphism were evaluated, no deviation from Hardy-Weinberg equilibrium was observed for neither the PCa patients $\left(\chi^{2}=1.123, \mathrm{p}=0.298\right)$ nor control groups $\left(\chi^{2}=0.323, \mathrm{p}=0.569\right)$. The genotype and allele frequencies of the CTLA-4 gene+49A/G polymorphism in the PCa patients and healthy controls are presented in Table 2 . The AG genotype for the CTLA-4 $(+49 \mathrm{~A} / \mathrm{G})$ gene polymorphism in the PCa patients and in the control group were 28 patients $(45 \%)$ and 43 healthy individuals $(36 \%)$ respectively. There was an increase in AG genotype frequency, but the difference was not statistically significant. The CTLA-4 (+49A/G) AA genotype was a predominant genotype of the CTLA- 4 exon 1 polymorphism in both the PCa patients and the healthy controls $(50 \%$, $56 \%$, respectively). CTLA-4 (+49A/G) AA genotype frequency was not statistically significant in the PCa patients compared to the healthy controls. The CTLA-4 (+49A/G) GG genotype frequency was low in both the PCa patients and the healthy controls $(5 \%, 8 \%$, respectively) (Table 2). There was no statistical significant difference determined between CTLA-4 gene $+49 \mathrm{~A} / \mathrm{G}$ genotype and allele frequencies in the PCa patients and the healthy controls.

Table 2 Distribution of genotype and allele frequencies of CTLA-4 gene+49A/G polymorphisms in the patients with prostate cancer (PCa) and the control groups

\begin{tabular}{lllllll}
\hline Gene/genotypes & & $\begin{array}{l}\text { Patients } \\
\mathbf{n}=62 \mathbf{n} / \%\end{array}$ & $\begin{array}{l}\text { Control groups } \\
\mathbf{n}=119 \mathbf{n} / \%\end{array}$ & P value & $\begin{array}{l}\text { Odds ratio } \\
\text { (OR) }\end{array}$ & $\mathbf{9 5 \% ( C I )}$ \\
\hline & AA & $31(50)$ & $67(56)$ & - & 1 & - \\
& AG & $28(45)$ & $43(36)$ & 0.294 & 0.711 & $0.375-1.346$ \\
$\begin{array}{l}\text { CTLA-4+49 A/les } \\
\text { AG }\end{array}$ & GG & $3(5)$ & $9(8)$ & 0.639 & 1.388 & $0.351-5.486$ \\
& AG+GG & $59(95)$ & $110(92)$ & 0.416 & 0.776 & $0.419-1.437$ \\
& A & $90(73)$ & $177(74)$ & & & $0.559-1.489$ \\
\hline
\end{tabular}




\section{Discussion}

Genetic factors are major at many steps in pathogenesis of cancer. ${ }^{1}$ CTLA-4 gene is well established that different alleles of this gene contribute to the susceptibility to diseases such as diabetes, systemic lupus erythematosus, breast cancer, osteosarcoma and cervical cancer. ${ }^{3,5,6,17,18}$ The CTLA-4 gene $+49 \mathrm{~A} / \mathrm{G}$ polymorphism corresponds to an amino acid exchange (threonine to alanine) in the leader peptide of the expressed protein. ${ }^{7}$ Cytotoxic T-lymphocyte antigen 4 (CTLA4) (cluster of differentiation 152 [CD152]) is a vital negative regulator of T-cell activation and proliferation., ${ }^{1,4}$ There are several studies reporting the associations between CTLA-4 polymorphisms and cancer. ${ }^{6,7}$ The CTLA-4 gene $+49 \mathrm{~A} / \mathrm{G}$ polymorphisms were identified as playing a significant role in the development of cancer. ${ }^{1,4}$ Ghaderi et al. ${ }^{7}$ in their study regarding the Iranian breast cancer patients, showed that there is a significant difference between frequency of CTLA4 genotypes in patients and controls. In addition, the frequency of GG genotype was significantly decreased in breast cancer patients compared to the controls $(4.6 \%$ v.s. $12.6 \%, \mathrm{P}=0.012)$. There was also a significant positive correlation between tumor size and the existence of AA genotype in patients $(\mathrm{P}=0.016)$. Furthermore, a positive correlation between AA genotype and lymph node involvement was observed $(\mathrm{P}=0.042)$. The results of the study conducted by Lieu et al. ${ }^{6}$ showed that rs 231775 polymorphism of CTLA-4 was associated with osteosarcoma risk (GG vs. AA: $\mathrm{OR}=1.63,95 \% \mathrm{CI}=1.24-2.13$; $\mathrm{GG}+\mathrm{GA}$ vs. $\mathrm{AA}: \mathrm{OR}=1.56,95 \% \mathrm{CI}=1.21-2.01 ; \mathrm{AA}+\mathrm{GA}$ vs. $\mathrm{GG}$ : $\mathrm{OR}=0.83,95 \% \mathrm{CI}=0.71-0.97 ; \mathrm{G}$ vs. $\mathrm{A}: \mathrm{OR}=1.21,95 \% \mathrm{CI}=1.08-1.36$ ).

Allele A and genotype AA of the CTLA-4 gene $+49 \mathrm{~A} / \mathrm{G}$ polymorphism were defined as the risk factors for cancer. The findings of Monne et al. ${ }^{19}$ indicate that the genotype and haplotype analysis showed the exon 1+49 AA genotype was over-represented among patients with Non-Hodgkin's Lymphoma (NHL). Farbod et al. ${ }^{8}$ investigated the potential influences of cytotoxic T-lymphocyte antigen-4 (CTLA-4) gene polymorphisms on breast cancer risk, the distribution of CTLA-4 single nucleotide polymorphisms (1661AG) in breast cancer patients and controls. According to the results of these studies, the AA genotype was associated with breast cancer, but none of the studied gene polymorphisms was associated with prognostic factors such as tumor stage, grade or size. ${ }^{8}$ These results of their studies confirm the findings of two other studies in Iran ${ }^{7}$ and China, ${ }^{20}$ which found GG genotype is more frequent in breast cancer patients. Erfani et al. ${ }^{21}$ genotyped 283 patients and 245 healthy control subjects for $21722 \mathrm{~T} / \mathrm{C}, 21661 \mathrm{~A} / \mathrm{G}$, and $2318 \mathrm{C} / \mathrm{T}$ single nucleotide polymorphisms in the promoter region of the CTLA4 gene. Erfani et al. ${ }^{21}$ found a relationship between AA genotype and lower lymph node involvement and higher ER expression. However, these researchers indicated that they did not find any difference between their study groups in terms of AG genotype. Erfani et al. ${ }^{21}$ identified a relationship between AG genotype and ER expression. Also, Li et al. ${ }^{20}$ observed a relationship among all CTLA-4 gene polymorphisms with estrogen and progesterone receptors, which was not consistent with our findings.

In another study by Karabon et al., ${ }^{22}$ SNPs in CTLA-4 and CD28 genes were genotyped in 301 prostate cancer $(\mathrm{PCa})$ patients and 301 controls. These researchers revealed that the frequency of alleles, and genotypes in the CTLA-4 and CD28 genes did not significantly differ between the PCa patients and the controls. That finding was in accordance with the frequency of alleles and genotypes in the CTLA-4 gene $+49 \mathrm{~A} / \mathrm{G}$ polymorphism of our study. These researchers reported that the CTLA-4c.49A $>$ G and CTLA-4g.319C $>$ T SNPs might be considered as low risk susceptibility locus for $\mathrm{PCa}{ }^{22}$ The limitation of the study is it cannot find the serum PSA level of control group.

\section{Conclusion}

In this study, the CTLA-4 gene $+49 \mathrm{~A} / \mathrm{G}$ polymorphism was investigated in the patients diagnosed with $\mathrm{PCa}$ and no statistically significant difference was determined between the patients and control groups. In addition, this study is significant in terms of reflecting the first findings related to the CTLA- 4 gene $+49 \mathrm{~A} / \mathrm{G}$ polymorphisms in patients with $\mathrm{PCa}$ in Turkey.

\section{Acknowledgements}

The author wishes to express their deep gratitude to the volunteers of this work for sincere cooperation.

\section{Conflict of interest}

There is no conflict of interest for this study.

\section{References}

1. Zhang Y, Zhang J, Deng Y, et al. Polymorphisms in the cytotoxic T-lymphocyte antigen 4 gene and cancer risk: a meta-analysis. Cancer. 2011;117(18):4312-4324.

2. Ma Y, Yang HZ, Dong BJ, et al. Biphasic regulation of autophagy by miR-96 in prostate cancer cells under hypoxia. Oncotarget. 2014;5(19):9169-9182.

3. Çelmeli F, Türkkahraman D, Özel D, et al. CTLA-4 (+49A/G) Polymorphism and type-1 diabetes in Turkish children. J Clin Res Pediatr Endocrinol. 2013;5(1):40-43.

4. Sun T, Hu Z, Shen H, et al. Genetic polymorphisms in cytotoxic T-lymphocyte antigen 4 and cancer: The dialectical nature of subtle human immune dysregulation. Cancer Res. 2009;69(15):6011-6014.

5. Wang L, Li D, Fu Z, et al. Association of CTLA-4 gene polymorphisms with sporadic breast cancer in chinese han population. BMC cancer. 2007;7(173):1-7.

6. Liu J, Wang J, Jiang W, et al. Effect of cytotoxic T-lymphocyte antigen-4, TNF-alpha polymorphisms on osteosarcoma: evidences from a meta-analysis. Chin J Cancer Res. 2013;25(6):671-678.

7. Ghaderi A, Yeganeh F, Kalantari T, et al. Cytotoxic T lymphocyte antigen-4 gene in breast cancer. Breast Cancer Res Treat. 2004;86(1):1-7.

8. Farbod M, Shiryazdi SM, Harazi H, et al. Association between the cytotoxic T-lymphocyte antigen-4 polymorphisms and breast cancer risk and prognosis. Journal of Cancer Metastasis and Treatment. 2015;1(1):1620.

9. Xiaolei L, Baohong Y, Haipeng R, et al. Current evidence on the cytotoxic T-lymphocyte antigen $4+49 \mathrm{G}>\mathrm{A}$ polymorphism and digestive system cancer risks: a meta-analysis involving 11,923 subjects. Meta gene. 2015;6:105-108.

10. Machida H, Tsukamoto K, Wen CY, et al. Association of polymorphic alleles of CTLA4 with inflammatory bowel disease in the Japanese. World J Gastroenterol. 2005;11(27):4188-4193.

11. Csöngei V, Járomi L, Sáfrány E, et al. Interaction between CTLA4 gene and IBD5 locus in Hungarian Crohn's disease patients. Int J Colorectal Dis. 2011;26(9):1119-1125.

12. Ben Alaya W, Sfar I, Aouadi H, et al. Association between CTLA-4gene promoter $(49 \mathrm{~A} / \mathrm{G})$ in exon 1 polymorphisms and inflammatory bowel disease in the Tunisian population. Saudi J Gastroenterol. 2009;15(1):29-34. 
13. Zalloua PA, Abchee A, Shbaklo H, et al. Patients with early onset of type 1 diabetes have significantly higher GG genotype at position 49 of the CTLA4 gene. Hum Immunol. 2004;65(7):719-24.

14. Wafai RJE, Chmaisse HN, Makki RF, et al. Association of HLA class II alleles and CTLA-4 polymorphism with type 1 diabetes. Saudi J Kidney Dis Transpl. 2011;22(2):273-281.

15. Uzer E, Dilmec F, Akkafa F, et al. Investigation of CTLA-4 and CD28 gene polymorphisms in patients with diabetes mellitus type 2 using PCRRFLP in a Turkish population. West Indian Med J. 2010;59(3):235-240.

16. Dilmec F, Ozgonul A, Uzunkoy A, et al. Investigation of CTLA-4 and CD28 gene polymorphisms in a group of Turkish patients with colorectal cancer. Int J Immunogenet. 2008;35(4-5):317-321.

17. Ulker M, Yazisiz V, Sallakci N, et al. CTLA-4 gene polymorphism of exon $1(+49 \mathrm{~A} / \mathrm{G})$ in Turkish systemic lupus erythematosus patients. Int J Immunogenet. 2009;36(4):245-250.

18. Gokhale P, Kerkar S, Tongaonkar H, et al. CTLA-4 gene polymorphism at position $\mathrm{D} 49 \mathrm{~A}>\mathrm{G}$ in exon 1: a risk factor for cervical cancer in Indian women. Cancer Genet. 2013;206(5):154-161.
19. Monne M, Piras G, Palmas A, et al. Cytotoxic T-lymphocyte antigen-4 (CTLA-4) gene polymorphism and susceptibility to non-hodgkin's lymphoma. Am J Hematol. 2004;76(1):14-18.

20. Li D, Zhang Q, Xu F, et al. Association of CTLA-4 gene polymorphisms with sporadic breast cancer risk and clinical features in han women of northeast China. Mol Cell Biochem. 2012;364((1-2):283-290.

21. Erfani N, Razmkhah M, Talei AR, et al. Cytotoxic T lymphocyte antigen-4 promoter variants in breast cancer. Cancer Genet Cytogenet. 2006;165(2):114-120.

22. Karabon L, Tupikowski K, Tomkiewicz A, et al. Is the genetic background of co-stimulatory CD28/CTLA-4 pathway the risk factor for prostate cancer. Pathol Oncol Res. 2017;23(4):837-843. 